\title{
Evaluation of the nuclear DNA content and GC percent in four varieties of Fagus sylvatica $\mathbf{L}$.
}

\author{
Anita Gallois ${ }^{\mathrm{a}}$, Monique Burrus ${ }^{\mathrm{a}}$, Spencer Brown ${ }^{\mathrm{b}}$

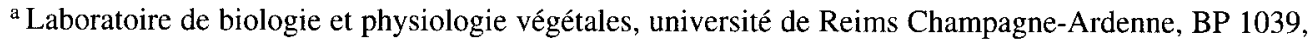 \\ 51687 Reims cedex 2, France \\ ${ }^{\text {b }}$ Laboratoire de cytométrie, ISV, CNRS 91198 Gif-sur-Yvette, France
}

(Received 7 October 1998; accepted 22 June 1999)

\begin{abstract}
The nuclear DNA content of Fagus sylvatica has been assessed for the first time by flow cytometry and propidium iodide staining. Three beech varieties were compared to the common beech: the tortuosa, the purpurea and the pendula varieties. Values were $2 \mathrm{C}=1.11 \pm 0.02,1.11 \pm 0.01,1.12 \pm 0.01$ and $1.13 \pm 0.01 \mathrm{pg}$, respectively. These are the first estimates of nuclear DNA content made in the Fagus genus. GC percent was estimated in the common beech and in the tortuosa variety with mithramycin. It was $40.0 \pm 0.2$ and $39.8 \pm 0.2 \%$, respectively, values typical of higher plants. (C) 1999 Éditions scientifiques et médicales Elsevier SAS.
\end{abstract}

Fagus sylvatica / flow cytometry / nuclear DNA content / GC percent

Résumé - Évaluation de la teneur en ADN nucléaire et pourcentage de GC chez quatre variétés de Fagus sylvatica L. La teneur en ADN nucléaire de Fagus sylvatica a été estimée pour la première fois par cytométrie en flux et coloration à l'iodure de propidium. Trois variétés de hêtre ont été comparées au hêtre commun: les variétés tortuosa, purpurea et pendula. Les valeurs obtenues étaient respectivement: $2 \mathrm{C}=1,11 \pm 0,02 \mathrm{pg}, 1,11 \pm 0,01 \mathrm{pg}, 1,12 \pm 0,01 \mathrm{pg}$, et $1,13 \pm 0,01 \mathrm{pg}$. Ce sont les premières estimations de la teneur en ADN nucléaire dans le genre Fagus. Les pourcentages de GC ont été estimées pour le hêtre commun et la variété tortuosa avec la mithramycine. Elles sont respectivement de $40,0 \pm 0,2 \%$ et $39,8 \pm 0,2 \%$, valeurs typiques des plantes supérieures. (C) 1999 Éditions scientifiques et médicales Elsevier SAS.

Fagus sylvatica / cytométrie en flux / contenu en ADN nucléaire / pourcentage de GC

\section{Introduction}

The common beech, Fagus sylvatica L., is one of the most important broad-leaf trees in Europe, found mainly in mountain areas. Although the common beech is known to possess $2 n=24$ chromosomes [1], no information concerning nuclear DNA content in the whole genus Fagus is available. Bennett and collegues [4-8] did not mention it in their extensive survey of
Angiosperm genome size. Although they studied the genome of many woody species, Ohri and Ahuja [21] did not measure the DNA content of $F$. sylvatica.

Genome size is, however, an essential parameter in many genetic and molecular biological studies [2]. In Angiosperms, haploid genome size varies from less than one picogram (pg) (Arabidopsis thaliana: $0.15 \mathrm{pg}$ ) [7] to more than $100 \mathrm{pg}$ (Fritillaria assyriaca: $127 \mathrm{pg}$ ) [18]. Among techniques used for genome studies, flow

* Correspondence and reprints
monique.burrus@univ-reims.fr 
cytometry is extremely rapid and convenient: it allows accurate determinations of nuclear DNA content [13] and of AT/GC base composition in a genome [15]. Favre and Brown [12] developed a fast and simple flow cytometry protocol for Quercus DNA content evaluation, based on high chelating capacity of the nuclear isolation buffer. We used this method to set up experimental conditions for Fagus. This study was performed in order to estimate nuclear DNA content in the common beech, compared to three other beech varieties, as well as to evaluate its GC content.

\section{Materials and methods}

Four varieties were used: the common beech $(F$. sylvatica $\mathrm{L}$.), the purple beech ( $F$. sylvatica var. purpurea Ait.), the twisted beech ( $F$. sylvatica var. tortuosa Pépin Willk.) and the weeping beech ( $F$. sylvatica var. pendula Lodd.). All the samples were collected near Reims, France $\left(49^{\circ} 14^{\prime} \mathrm{N}, 3^{\circ} 59 \mathrm{E}\right)$. The Petunia hybrida $\mathrm{cv}$ $\mathrm{P} \times \mathrm{Pc} 6(2 \mathrm{C}=2.85 \mathrm{pg}, 41 \% \mathrm{GC})[15]$ was selected as an internal standard. Four plants per variety were randomly chosen and separately analysed. For each plant, two leaves were separately chopped, and two independent measures were performed on each leaf extract.

Healthy leaves were collected from mature trees and rinsed thoroughly with distilled water before slicing. Fresh leaf fragments (ca. $1 \mathrm{~cm}^{2}$ ) were chopped at room temperature with a razor blade, together with a leaf fragment of another plant when mentioned, in $500 \mu \mathrm{L}$ of Galbraith's nuclear isolation buffer [14] with $0.5 \%$ Triton $\mathrm{X}-100$ and sodium metabisulfite $(10 \mathrm{mM})$ as an antioxidant. The crude extract was filtered through $48 \mu \mathrm{m}$ nylon mesh and kept on ice until further use.

Initially, experimental conditions were established using DAPI, $3 \mu \mathrm{g}$ per $\mathrm{mL}$, in nuclear isolation buffer. Subsequently, total nuclear DNA was assessed after a 30 min incubation with RNase, $100 \mu \mathrm{g}(5 \mathrm{U})$ per $\mathrm{mL}$, and propidium iodide staining, $50 \mu \mathrm{g} \mathrm{mL}^{-1}$. The proportion of GC was measured separately, using mithramycin, $30 \mu \mathrm{g} \mathrm{mL}{ }^{-1}$, as specific dye [15].

Stained nuclei were passed through an EPICS V cytometer (Coulter, Fl, USA) equipped with an Argon ion laser (Spectra-Physics 2025-05) exciting at $514 \mathrm{~nm}$ for propidium iodide, $458 \mathrm{~nm}$ for mithramycin, or $351+364 \mathrm{~nm}$ for DAPI (for further information on the method, see $[10,18])$. At least 2500 nuclei were examined each time to assess the intensity of $2 \mathrm{C}$ Fagus nuclei relative to $2 \mathrm{C}$ Petunia nuclei.

Conversion of mass values into base-pair number was carried out according to Bennett and Smith [6]:
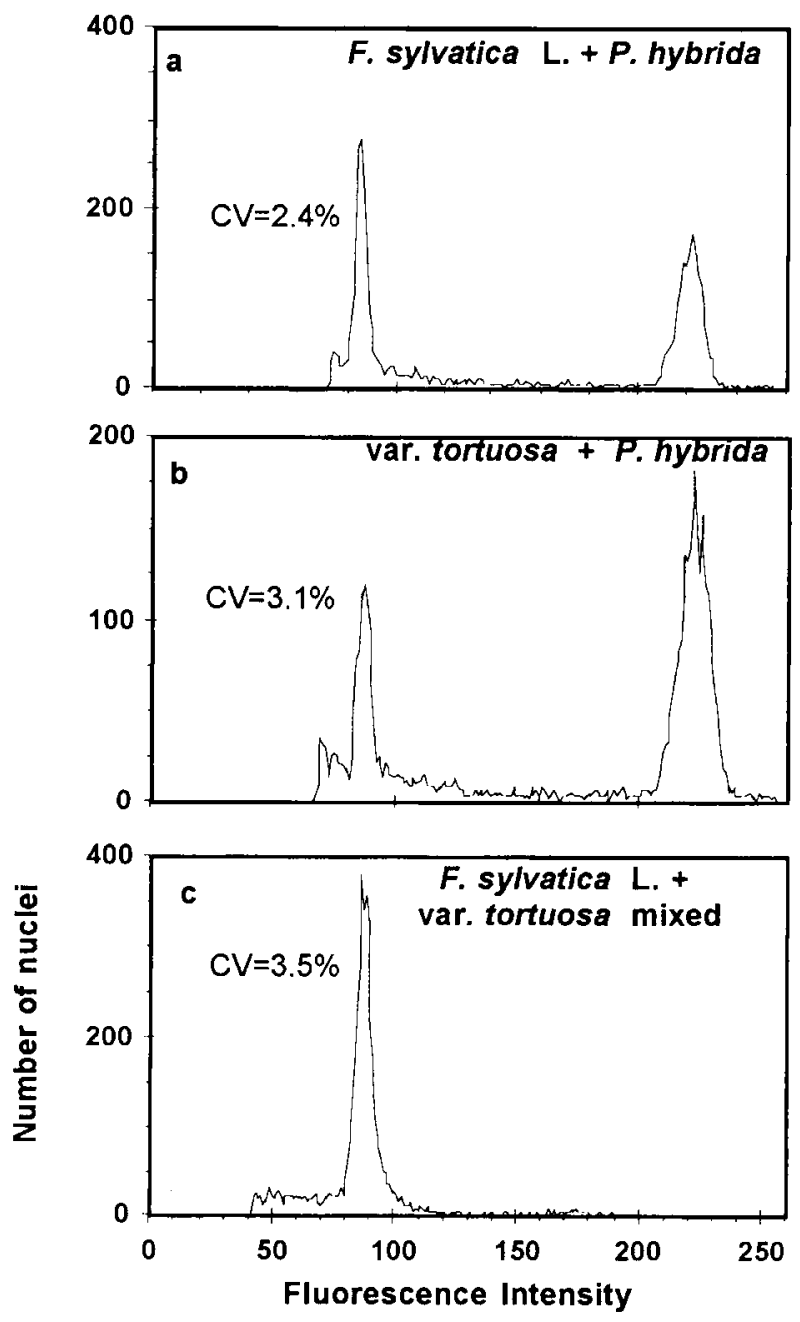

Figure 1. Histograms of relative propidium iodide fluorescence in nuclei from leaves of: a) $F$. sylvatica (common beech) and b) $F$. sylvatica var. tortuosa, both chopped in Galbraith buffer $(0.5 \%$ Triton X-100) in presence of $P$. hybrida leaf as an internal standard. c) Leaves of both beech varieties were mixed and chopped, without $P$. hybrida. The single peak of these $2 \mathrm{C}$ nuclei has the same dispersion $(\mathrm{CV}=3.5 \%)$ as analyses of individual specimens made on the same occasion.

$1 \mathrm{pg}=965 \mathrm{Mbp}$. The proportion of GC was determined using the relationship of Godelle et al. [15]:

$$
\% \mathrm{GC}_{\text {Fagus }}=\% \mathrm{GC}_{\text {Petunia }}\left(\mathrm{R}_{\mathrm{Mi}} / \mathrm{R}_{\mathrm{Pi}}\right)^{1 / 3}
$$

where $\mathrm{R}_{\mathrm{Mi}_{\mathrm{i}}=}$ intensity $\mathrm{Fagus}_{\text {intensity }}$ Petunia $_{\text {for mithramycin }}$ $\mathrm{R}_{\mathrm{Pi}=}$ intensity $_{\mathrm{Fagus}}$ /intensity $_{\text {Petunia }}$ for propidium iodide Statistical $t$-test was performed for DNA content comparison. 
Table I. Flow cytometric comparison and 2C nuclear DNA content of four $F$. sylvatica varieties (propidium iodide staining). Four independent trees per variety, each test involving two different leaves of the test sample, and two different measures per leaf extract. The mean channel number of each Fagus tree and Petunia sample, the mean ratio and their corresponding standard deviation (S.D.), and the DNA content are given.

\begin{tabular}{|c|c|c|c|c|c|}
\hline Variety & $\begin{array}{c}\text { Tree } \\
\text { sample } \\
\text { number }\end{array}$ & $\begin{array}{c}\text { Mean } \\
\text { channel number } \\
\text { Fagus/Petunia }\end{array}$ & $\begin{array}{l}\text { Relative } \\
\text { intensity } \\
\text { ratio (SD) }\end{array}$ & $\begin{array}{c}2 \mathrm{C} \\
\text { nuclear DNA } \\
\text { pg (SD) }\end{array}$ & $\begin{array}{c}2 \mathrm{C} \\
\text { nuclear DNA } \\
\text { Mbp }\end{array}$ \\
\hline tortuosa & $\begin{array}{c}1 \\
2 \\
3 \\
4 \\
\text { mean }\end{array}$ & $\begin{array}{l}85 / 217 \\
81 / 209 \\
82 / 212 \\
85 / 216\end{array}$ & $\begin{array}{l}0.392(0.002) \\
0.388(0.002) \\
0.388(0.005) \\
0.391(0.002) \\
0.390(0.002)\end{array}$ & $1.11(0.01)$ & 1070 \\
\hline purpurea & $\begin{array}{c}1 \\
2 \\
3 \\
4 \\
\text { mean }\end{array}$ & $\begin{array}{l}88 / 225 \\
84 / 216 \\
92 / 232 \\
83 / 213\end{array}$ & $\begin{array}{l}0.391(0.000) \\
0.388(0.000) \\
0.398(0.002) \\
0.390(0.000) \\
0.392(0.004)\end{array}$ & $1.12(0.01)$ & 1080 \\
\hline
\end{tabular}

Table II. Base composition in GC \% in Fagus sylvatica and the tortuosa variety.

Two independent $F$. sylvatica trees and one tortuosa tree, each test involving two different leaves of the test sample, and two different measures per leaf extract. The mean relative fluorescent intensity of each Fagus and Petunia sample for both stainings and the mean $\mathrm{GC} \%$ per variety are given.

\begin{tabular}{lcccc}
\hline Variety & $\begin{array}{c}\text { Tree sample } \\
\text { number }\end{array}$ & $\begin{array}{c}\text { Relative fluorescent intensity ratio } \\
\text { Fagus/Petunia (propidium iodide) }\end{array}$ & $\begin{array}{c}\text { Relative fluorescent intensity ratio } \\
\text { Fagus/Petunia (mithramycin) }\end{array}$ & $\begin{array}{c}\text { Base composition } \\
\text { GC \% (SD) }\end{array}$ \\
\hline F. sylvatica L. & 1 & 0.383 & 0.352 \\
& 2 & 0.388 & 0.364 & 0.359 \\
tortuosa & mean & 0.386 & 0.357 & $30.0(0.2)$ \\
\hline
\end{tabular}

\section{Results and discussion}

In a first set of experiments, nuclei of common beech stained with propidium iodide were run concurrently with nuclei of Petunia hybrida (figure la). Two distinct major peaks were visible, one for Petunia (relative fluorescence: channel 222), the second for $F$. sylvatica (relative fluorescence: channel 86), with a low coefficient of variation $(2.4 \%)$. Similar fluorescence distribution was obtained for Petunia and tortuosa nuclei run simultaneously (figure 1 b). In order to verify whether the fluores- cence channels were identical for the common beech and the tortuosa variety, both nuclei populations were run concurrently (figure $1 \mathrm{c}$ ). One single peak was observed (relative fluorescence: channel 87; $\mathrm{CV}=3.5 \%$ ), indicating that DNA content in the tortuosa variety is the same as in the common beech. Furthermore, in replicated analyses of common beech with or without tortuosa, the coefficients of variation were tight and independent of whether or not two varieties were present.

We then measured DNA content for all four varieties. Table I shows mean relative fluorescence after propidi- 
um iodide staining. In 16 histograms, the average coefficient of variation for the peak of $2 \mathrm{C}$ nuclei for Petunia was $2.2 \%$ and that of Fagus $3.1 \%$, altogether acceptable. $2 \mathrm{C}$ DNA values converted to $\mathrm{pg}$ amounts and to Mbp are listed on table I. They range from $1.11 \pm 0.02$ pg for the common beech to $1.13 \pm 0.01 \mathrm{pg}$ for the pen$d u l a$ variety. These results show a relatively uniform nuclear DNA content among the varieties of $F$. sylvatica, except that the pendula differs significantly from the tortuosa variety at $P=0.001$. No clear intraspecific variation was evident, although it has been observed in several diploid species $[3,9,17,19]$.

Compared to Quercus, the only genus of the Fagaceae family whose genome size is known, $F$. sylvatica genomes are smaller: according to a flow cytometry estimation [12], the genome size of $Q$. robur is: $2 \mathrm{C}=1.84 \pm 0.01 \mathrm{pg}$ and of $Q$. petraea: $2 \mathrm{C}=1.87 \pm 0.02$ pg. Using microdensitometry methods, Greilhuber evaluated the genome of $Q$. petraea to $2 \mathrm{C}=1.8 \mathrm{pg}$ [16], and Ohri and Ahuja [20] to $1.58 \mathrm{pg}$. Although their DNA contents are different, these two genera have the same number of chromosomes $(2 n=24)$ and the chromosome morphology is similar, as shown by C-banding $[20,21]$.

This analysis revealed that $F$. sylvatica is situated at the low end of the range of known 2C genome sizes, as for instance Musa acuminata (1.2 pg), Vitis vinifera (1.0 pg) or Phaseolus augustii (1.1 pg) [4, 11].

The GC content was then determined for the common beech and the tortuosa variety, after propidium iodide and mithramycin stainings. Results are listed in table II. In $F$. sylvatica, the GC content was $40.0 \pm 0.2 \%$; in the tortuosa variety, $39.8 \pm 0.2 \%$. These values are not significantly different and they are typical for higher plants. Compared to the GC content found in the Quercus genus, they are slightly lower. The GC content was evaluated at $41.7 \%$ for $Q$. petraea, $42.0 \%$ for $Q$. robur, and $42.1 \%$ for $Q$. pubescens [12]. Other values in the Fagaceae family have not yet been determined.

Acknowledgements: The authors thank Ms D. De Nay and Mr J.M. Bureau for technical assistance and advice.

\section{References}

[1] Becker M., Taxonomie et caractères botaniques, in: INRA (Ed.), Le Hêtre, Tec Doc, Paris, 1981, pp. 35-46.

[2] Bennett M.D., The genome, the natural karyotype and biosystematics, in: Grant W.F. (Ed.), Plant Biosystematics, Academic Press, San Diego, CA, 1984, pp. 41-66.

[3] Bennett M.D., Variation in genomic form in plants and its ecological implication, New Phytol. 106 (1987) 177-200.
[4] Bennett M.D., Leitch I., Nuclear DNA amounts in angiosperms, Ann. Bot. 76 (1995) 113-176.

[5] Bennett M.D., Leitch I., Nuclear DNA amounts in angiosperms - 583 new estimates, Ann. Bot. 80 (1997) 169-196.

[6] Bennett M.D., Smith J.B., Nuclear DNA amounts in angiosperms, Phil. Trans. R. Soc. London B 274 (1976) 227-274.

[7] Bennett M.D., Smith J.B., Nuclear DNA amounts in angiosperms, Phil. Trans. R. Soc. London B 334 (1991) 309-345.

[8] Bennett M.D., Smith J.B., Heslop-Harrison J.S., Nuclear DNA amounts in angiosperms, Proc. R. Soc. London Ser. B 216 (1982) 179-199.

[9] Blondon F., Marie D., Brown S., Kondorosi A., Genome size and base composition in Medicago sativa and M. truncatula species, Genome 37 (1994) 264-270.

[10] Brown S.C., Bergounioux C., Tallet S., Marie D., Flow cytometry of nuclei for ploidy and cell cycle analysis, in: Negrutiu I., Gharti-Chhetri G. (Eds.), A Laboratory Guide for Cellular and Molecular Plant Biology, Birkhäuser, Basel, Switzerland, 1991, pp. 326-345.

[11] Dolezel J., Dolezelova M., Novak F.J., Flow cytometric estimation of nuclear DNA amount in diploid bananas (Musa acuminata and M. balbisiana), Biol. Plant. 36 (1994) $351-357$.

[12] Favre J.M., Brown S., A flow cytometric evaluation of the nuclear DNA content and GC percent in genomes of European oak species, Ann. Sci. For. 53 (1996) 915-917.

[13] Galbraith D.W., Flow cytometric analysis of plant genomes, in: Darzynkiewicz Z., Crissman H.A. (Eds.), Methods in Cell Biology, vol. 33., Academic, San Diego, CA, 1990, pp. 549-563

[14] Galbraith D.W., Harkins K.R., Maddox J.M., Ayres N.M., Sharma D.P., Firoozabady E., Rapid flow cytophotometric analysis of the cell cycle in intact plant tissues, Science 220 (1983) 1049-1051.

[15] Godelle B., Cartier D., Marie D., Brown S.C., SiljakYakovlev S., Heterochromatin study demonstrating the nonlinearity of fluorometry useful for calculating genomic base composition, Cytometry 14 (1993) 618-626.

[16] Greilhuber J., "Self-tanning" a new and important source of stoichiometric error in cytophotometric determination of nuclear DNA content in plants, Plant Syst. Evol. 158 (1988) $87-96$.

[17] Laurie D.A., Bennett M.D., Nuclear DNA content in the genera Zea and Sorghum. Intergeneric, interspecific and intraspecific variation, Heredity 55 (1985) 307-313.

[18] Marie D., Brown S.C., A cytometric exercise in plant DNA histograms, with $2 \mathrm{C}$ values for seventy species, Biol. Cell 78 (1993) 41-551.

[19] Michaelson M.J., Price H.J., Johnston J.S., Ellison J.R., Variation of nuclear DNA content in Helianthus annuus (Asteraceae), Am. J. Bot. 78 (1991) 1238-1243.

[20] Ohri D., Ahuja M.R., Giemsa C-banded karyotype in Quercus L. (oak), Silvae Genet. 39 (1990) 216-219.

[21] Ohri D., Ahuja M.R., Giemsa C-banding in Fagus sylvatica L., Betula pendula Roth and Populus tremula L., Silvae Genet. 40 (1991) 72-75. 